Atmos. Chem. Phys., 14, 1025-1038, 2014

www.atmos-chem-phys.net/14/1025/2014/

doi:10.5194/acp-14-1025-2014

(c) Author(s) 2014. CC Attribution 3.0 License.

\title{
Middle atmospheric changes caused by the January and March 2012 solar proton events
}

\author{
C. H. Jackman ${ }^{1}$, C. E. Randall ${ }^{2}$, V. L. Harvey ${ }^{2}$, S. Wang $^{3}$, E. L. Fleming ${ }^{1,4}$, M. López-Puertas ${ }^{5}$, B. Funke , and $^{5}$ \\ P. F. Bernath ${ }^{6,7}$ \\ ${ }^{1}$ NASA Goddard Space Flight Center, Code 614, Greenbelt, MD, USA \\ ${ }^{2}$ Laboratory for Atmospheric and Space Physics and Department of Atmospheric and Oceanic Sciences, University of \\ Colorado, Boulder, CO, USA \\ ${ }^{3}$ Jet Propulsion Laboratory, California Institute of Technology, Pasadena, CA, USA \\ ${ }^{4}$ Science Systems and Applications, Inc., Lanham, MD, USA \\ ${ }^{5}$ Instituto de-Astrofisica de Andalucia, CSIC, Granada, Spain \\ ${ }^{6}$ Department of Chemistry and Biochemistry, Old Dominion University, Norfolk, VA, USA \\ ${ }^{7}$ Department of Chemistry, University of York, York, UK
}

Correspondence to: C. H. Jackman (charles.h.jackman@ nasa.gov)

Received: 9 July 2013 - Published in Atmos. Chem. Phys. Discuss.: 4 September 2013

Revised: 12 December 2013 - Accepted: 14 December 2013 - Published: 29 January 2014

\begin{abstract}
The recent 23-30 January and 7-11 March 2012 solar proton event (SPE) periods were substantial and caused significant impacts on the middle atmosphere. These were the two largest SPE periods of solar cycle 24 so far. The highly energetic solar protons produced considerable ionization of the neutral atmosphere as well as $\mathrm{HO}_{\mathrm{x}}(\mathrm{H}, \mathrm{OH}$, $\left.\mathrm{HO}_{2}\right)$ and $\mathrm{NO}_{\mathrm{x}}\left(\mathrm{N}, \mathrm{NO}, \mathrm{NO}_{2}\right)$. We compute a $\mathrm{NO}_{\mathrm{x}}$ production of 1.9 and 2.1 Gigamoles due to these SPE periods in January and March 2012, respectively, which places these SPE periods among the 12 largest in the past $50 \mathrm{yr}$. Aura Microwave Limb Sounder (MLS) observations of the peroxy radical, $\mathrm{HO}_{2}$, show significant enhancements of $>0.9 \mathrm{ppbv}$ in the northern polar mesosphere as a result of these SPE periods. Both MLS measurements and Goddard Space Flight Center (GSFC) two-dimensional (2-D) model predictions indicated middle mesospheric ozone decreases of $>20 \%$ for several days in the northern polar region with maximum depletions $>60 \%$ over $1-2$ days as a result of the $\mathrm{HO}_{\mathrm{x}}$ produced in both the January and March 2012 SPE periods. The SCISAT-1 Atmospheric Chemistry Experiment Fourier Transform Spectrometer (ACE) and the Envisat Michelson Interferometer for Passive Atmospheric Sounding (MIPAS) instruments measured $\mathrm{NO}$ and $\mathrm{NO}_{2}\left(\sim \mathrm{NO}_{\mathrm{x}}\right)$, which indicated enhancements of over $20 \mathrm{ppbv}$ in most of the northern polar mesosphere for several days as a result of these SPE pe-
\end{abstract}

riods. The GSFC 2-D model and the Global Modeling Initiative three-dimensional chemistry and transport model were used to predict the medium-term ( $\sim$ months) influence and showed that the polar middle atmospheric ozone was most affected by these solar events in the Southern Hemisphere due to the increased downward motion in the fall and early winter. The downward transport moved the SPE-produced $\mathrm{NO}_{\mathrm{y}}$ to lower altitudes and led to predicted modest destruction of ozone (5-13\%) in the upper stratosphere days to weeks after the March 2012 event. Polar total ozone reductions were predicted to be a maximum of $1.5 \%$ in 2012 due to these SPEs.

\section{Introduction}

Solar flares erupted in January and March 2012 and sent large fluxes of charged particles towards the Earth. Much of the energy was carried by solar protons, which impacted the middle atmosphere (stratosphere and mesosphere) leading to ionizations, dissociations, dissociative ionizations, and excitations. Such periods are generally known as solar proton events (SPEs) and cause proton-induced atmospheric interactions resulting in the production of $\mathrm{HO}_{\mathrm{x}}\left(\mathrm{H}, \mathrm{OH}, \mathrm{HO}_{2}\right)$, and $\mathrm{NO}_{\mathrm{x}}\left(\mathrm{N}, \mathrm{NO}, \mathrm{NO}_{2}\right)$ constituents either directly or through 
a photochemical sequence in the polar middle atmosphere. Such $\mathrm{HO}_{\mathrm{x}}$ and $\mathrm{NO}_{\mathrm{x}}$ enhancements can then lead to a perturbation of ozone.

The major influence of these eruptions caused enhanced solar proton flux levels above background at the Earth for several days in January and March 2012. Although SPEs and their middle atmospheric constituent influences have been studied before (e.g., Swider and Keneshea, 1973; Heath et al., 1977; Solomon et al., 1981; McPeters and Jackman, 1985; Randall et al., 2001; López-Puertas et al., 2005a; von Clarmann et al., 2005; Verronen et al., 2006, 2008, 2011a, b; Krivolutsky et al., 2006; Funke et al., 2011; Jackman et al., 1990, 2001, 2005, 2007, 2008, 2009, 2011; Sinnhuber et al., 2012), each new event offers a chance to investigate the SPE-caused atmospheric perturbation under somewhat different conditions. Also, such events have been shown to cause some longer lasting stratospheric changes (e.g., Randall et al., 2001; Jackman et al., 2008, 2009) and need to be considered within the context of other ongoing stratospheric changes (WMO, 2011).

The recent study of von Clarmann et al. (2013) showed several atmospheric constituent changes due to the January and March 2012 SPEs using Envisat Michelson Interferometer for Passive Atmospheric Sounding (MIPAS) instrument measurements. These latest large events, which provided very significant middle atmospheric impulses over short ( $\sim$ days) periods of time, also offer new opportunities to test the general understanding of an atmospheric change caused by very substantial perturbations.

For example, the January 2012 SPE period occurred in the Northern Hemisphere $(\mathrm{NH})$ winter and Southern Hemisphere (SH) summer. The solar zenith angle (SZA) was very different in the $\mathrm{NH}$ and $\mathrm{SH}$ polar regions for this month of the year. Since the SZA dramatically impacts the background atmosphere upon which the SPE-caused perturbation interacts, the ultimate SPE-caused atmospheric variation is highly dependent on the SZA. The influences of the SPE-produced $\mathrm{HO}_{\mathrm{x}}$ and $\mathrm{NO}_{\mathrm{x}}$ species impacted ozone somewhat differently in the two hemispheres in January. Also, the $\mathrm{NH}$ was subject to a sudden stratospheric warming (SSW) event along with a mesospheric cooling in January (e.g., von Clarmann et al., 2013 and Päivärinta et al., 2013).

The March 2012 SPE period occurred closer to equinox for the two hemispheres, however, the NH was transitioning to spring and the $\mathrm{SH}$ was transitioning to fall. This meant that the SPE-caused $\mathrm{NO}_{\mathrm{x}}$ was transported somewhat differently in the two hemispheres and had a larger impact on ozone in the $\mathrm{SH}$ than in the $\mathrm{NH}$.

We will show the measured influence of these SPEs on $\mathrm{HO}_{2}$ and ozone from the Aura Microwave Limb Sounder (MLS) instrument. The influence of these SPEs on the sum of $\mathrm{NO}$ and $\mathrm{NO}_{2}\left(\sim \mathrm{NO}_{\mathrm{x}}\right)$ from the SCISAT-1 Atmospheric Chemistry Experiment Fourier Transform Spectrometer (ACE-FTS) and the Envisat MIPAS instruments will also be shown. These observations of the atmospheric response to the January and March 2012 SPE periods will be compared with global model predictions.

This paper is divided into seven primary sections, including the Introduction. The solar proton flux and ionization rate computation are discussed in Sect. 2 and SPE-induced production of $\mathrm{HO}_{\mathrm{x}}$ and $\mathrm{NO}_{\mathrm{x}}$ are discussed in Sect. 3. A description of the Goddard Space Flight Center two-dimensional model and the Global Modeling Initiative three-dimensional chemistry transport model is given in Sect. 4. Results from the two models for short-term (days) constituent changes, with comparisons to measurements for these SPEs, are shown in Sect. 5 while medium-term (months) constituent changes caused by these SPEs are discussed in Sect. 6. The conclusions are presented in Sect. 7.

\section{Proton flux and ionization rate}

We use the solar proton flux (energies 1 to $300 \mathrm{MeV}$ ) provided by the National Oceanic and Atmospheric Administration (NOAA) Space Weather Prediction Center (SWPC) for the NOAA Geostationary Operational Environmental Satellites (GOES) (see http://www.swpc.noaa.gov/ftpmenu/lists/ particle.html). The GOES 13 data are considered to be the most reliable of the current GOES datasets for the proton fluxes depositing energy into polar latitudes and were used as the source of protons in several energy intervals for the very active time periods 23-30 January 2012 and 7-11 March 2012. For example, the GOES proton flux during the 22-30 January 2012 time period is given in Fig. 1 (Top) for several different energies $(>1,>10,>30,>50$, and $>100 \mathrm{MeV}$ ). Note that the proton flux levels increased by a factor of a thousand or more for energies $>10,>30$, and $>50 \mathrm{MeV}$ on 23 January 2012. Four days later (27 January) another event led to proton flux levels increasing by a factor of more than a hundred for $>30,>50$, and $>100 \mathrm{MeV}$.

The proton flux data were used to compute the ion pair production profiles employing the energy deposition methodology discussed in Jackman et al. (1980), where the creation of one ion pair was assumed to require $35 \mathrm{eV}$ (Porter et al., 1976). The SPE-produced daily average ionization rates for the polar cap regions ( $>60^{\circ}$ geomagnetic latitude) are given in Fig. 1 (Bottom) for a nine day period in January 2012 from $10 \mathrm{hPa}(\sim 30 \mathrm{~km})$ to $0.001 \mathrm{hPa}(\sim 95 \mathrm{~km})$. Peak ionization rates above $2000 \mathrm{~cm}^{-3} \mathrm{~s}^{-1}$ on 24 January were computed for the 0.01 to $0.2 \mathrm{hPa}$ region. The ionization was greatly diminished by 26 January, but then the second SPE started late on 27 January and reached a peak on 28 January (also, see Fig. 1, Top).

The GOES proton flux during the 6-11 March 2012 time period is given in Fig. 2 (Top) for the same proton energies as in Fig. 1 (Top). The proton flux levels increased by a factor of a thousand or more for several energies (from $>10$ through $>100 \mathrm{MeV}$ ) on 7-8 March 2012. The SPEproduced daily average ionization rates during this event for 


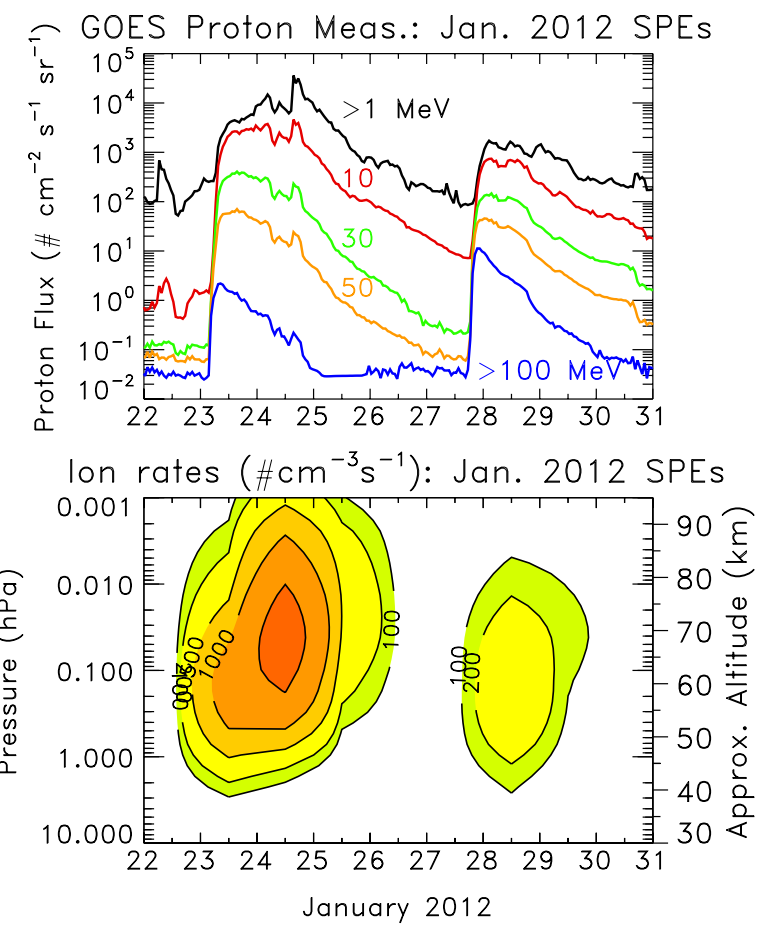

Fig. 1. (Top) GOES 13 proton flux measurements in January 2012 for energies > $1 \mathrm{MeV}$ (black), >10 MeV (red), > $30 \mathrm{MeV}$ (green), $>50 \mathrm{MeV}$ (gold), and $>100 \mathrm{MeV}$ (blue). These data are provided by the NOAA SWPC at their website (see Sect. 2). (Bottom) Daily averaged ionization rates over the 10 to $0.001 \mathrm{hPa}$ pressure range for the 22-30 January 2012 time period. Contour intervals are 100, 200, 500, 1000, and $2000\left(\# \mathrm{~cm}^{-3} \mathrm{~s}^{-1}\right)$.

the polar cap regions are given in Fig. 2 (Bottom). Peak ionization rates above $2000 \mathrm{~cm}^{-3} \mathrm{~s}^{-1}$ on 8 March were computed for the 0.01 to $0.3 \mathrm{hPa}$ region. Large ionization rates $>100 \mathrm{~cm}^{-3} \mathrm{~s}^{-1}$ are computed all the way down to $10 \mathrm{hPa}$ on 7-8 March. As illustrated in Fig. 2 (Top) compared with Fig. 1 (Top), this SPE period consisted of a larger flux of protons at higher energies $(>100 \mathrm{MeV})$ than were present in the January 2012 SPE period. The ionization is greatly diminished by 11 March.

\section{$3 \mathrm{HO}_{\mathrm{x}}\left(\mathrm{H}, \mathrm{OH}, \mathrm{HO}_{2}\right)$ and $\mathrm{NO}_{\mathrm{x}}\left(\mathrm{N}, \mathrm{NO}, \mathrm{NO}_{2}\right)$ production}

Charged particle precipitation results in the production of $\mathrm{HO}_{\mathrm{x}}$ through complex positive ion chemistry (Solomon et al., 1981). The charged particle-produced $\mathrm{HO}_{\mathrm{x}}$ is a function of ion pair production and altitude and is included in model simulations using a lookup table from Jackman et al. (2005, Table 1), which is based on the work of Solomon et al. (1981). Each ion pair results in the production of about two $\mathrm{HO}_{\mathrm{x}}$ constituents for the upper stratosphere and lower mesosphere and less than two $\mathrm{HO}_{\mathrm{x}}$ constituents for the middle and upper mesosphere.

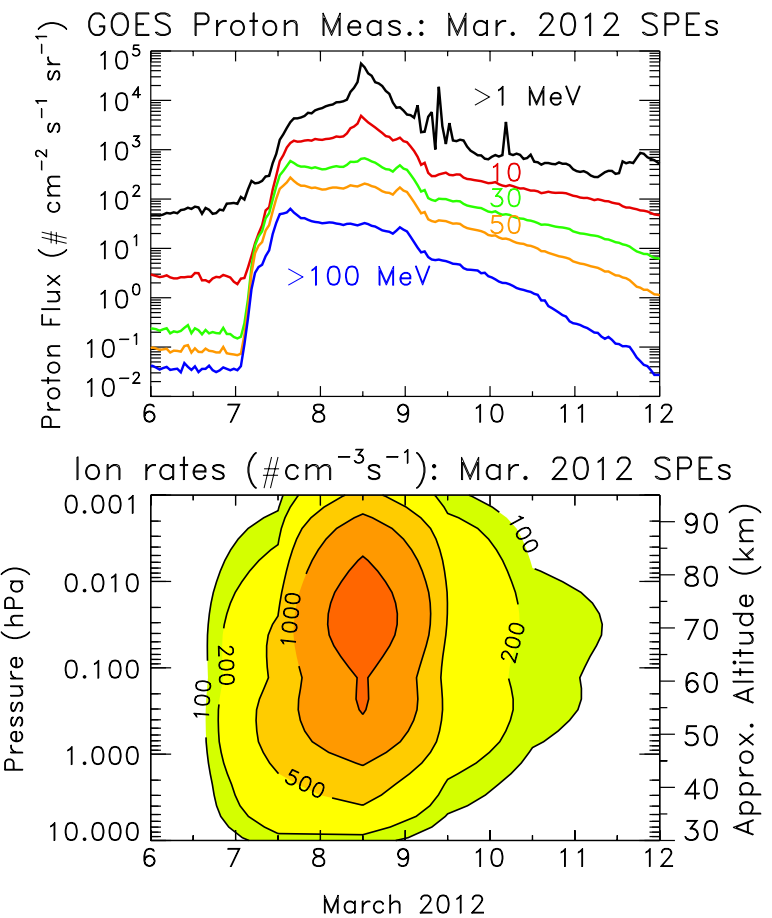

Fig. 2. (Top) GOES 13 proton flux measurements in March 2012 for energies $>1 \mathrm{MeV}$ (black), >10 MeV (red), > $30 \mathrm{MeV}$ (green), $>50 \mathrm{MeV}$ (gold), and $>100 \mathrm{MeV}$ (blue). These data are provided by the NOAA SWPC at their website (see Sect. 2). (Bottom) Daily averaged ionization rates over the 10 to $0.001 \mathrm{hPa}$ pressure range for the 6-11 March 2012 time period. Contour intervals are 100, 200, 500, 1000, and $2000\left(\# \mathrm{~cm}^{-3} \mathrm{~s}^{-1}\right)$.

$\mathrm{NO}_{\mathrm{x}}$ is produced when the energetic charged particles (protons and associated secondary electrons) dissociate $\mathrm{N}_{2}$ as they precipitate into the atmosphere. Here it is assumed that $\sim 1.25 \mathrm{~N}$ atoms are produced per ion pair and the proton impact of $\mathrm{N}$ atom production is divided between the ground state $\mathrm{N}\left({ }^{4} \mathrm{~S}\right)(\sim 45 \%$ or $\sim 0.55$ per ion pair $)$ and excited state $\mathrm{N}\left({ }^{2} \mathrm{D}\right)(\sim 55 \%$ or $\sim 0.7$ per ion pair) nitrogen atoms (Porter et al., 1976). We calculate that the 23-30 January 2012 SPE period produced about 1.9 Gigamoles of $\mathrm{NO}_{\mathrm{x}}$ and that the 7-11 March 2012 SPE period produced about 2.1 Gigamoles of $\mathrm{NO}_{\mathrm{x}}$. Thus, the January 2012 and the March 2012 SPE periods were computed to be the twelfth and tenth largest in the past $50 \mathrm{yr}$, respectively (see Jackman et al., 2008).

\section{Model predictions}

\subsection{Description of the GSFC 2-D model}

The latest version of the Goddard Space Flight Center (GSFC) two-dimensional (2-D) atmospheric model was used to predict the impact of solar protons on the atmosphere. This model was first discussed over $20 \mathrm{yr}$ ago (Douglass et al., 1989; Jackman et al., 1990) and has undergone extensive 
improvements over the years (e.g., Considine et al., 1994; Jackman et al., 1996; Fleming et al., 1999, 2007, 2011). The vertical range of the model, equally spaced in log pressure, is from the ground to approximately $92 \mathrm{~km}(0.0024 \mathrm{hPa})$ with a $1 \mathrm{~km}$ grid spacing. The model has a $4^{\circ}$ latitude grid spacing.

For this study, the transport is computed off-line and is derived using the daily average global winds and temperatures from the NASA Modern Era Retrospective-analysis for Research and Applications (MERRA) meteorological analysis (see the website: http://gmao.gsfc.nasa.gov/research/merra/) for 1979-2012. Thirty-day running averages of the residual circulation, eddy diffusion, zonal mean wind, and zonal mean temperature are computed using the methodology detailed in Fleming et al. (2007), and are used as input into the GSFC 2-D model. For this paper we used the transport fields for the year 2012, which included the January SSW.

The ground boundary conditions in the GSFC 2-D model for the source gases are taken from WMO (2011) for year 2012. The model uses a chemical solver described in Jackman et al. (2005) and Fleming et al. (2007, 2011). The photochemical gas and heterogeneous reaction rates and photolysis cross sections have been updated to the latest Jet Propulsion Laboratory recommendations (Sander et al., 2010) for these computations.

\subsection{Simulations of the GSFC 2-D model}

The starting conditions for the two GSFC 2-D model simulations used in this study were provided by a time dependent "spin-up" simulation from January 2000-December 2011, which included the appropriate source gas boundary conditions from WMO (2011) and the changing transport fields derived from MERRA for this time period. Two timedependent simulations, "A" and "B", were continued over the period 1 January through 31 December 2012. Simulation "A" included no SPEs and simulation "B" included all SPEs in this period.

\subsection{Description of the GMI 3-D CTM}

The Global Modeling Initiative (GMI) three-dimensional (3D) chemistry and transport model (CTM) was also used in this study. The GMI 3-D CTM is well suited to simulate the SPE-produced $\mathrm{NO}_{\mathrm{x}}$ in the lower mesosphere and throughout the stratosphere during 2012 . The $1^{\circ} \times 1.25^{\circ}$ horizontal resolution of the latest version of the GMI 3-D CTM (Strahan et al., 2013) uses MERRA meteorological fields for the time periods under investigation. More information about the GMI 3-D CTM and its chemical mechanism can be found in Strahan et al. (2007) and Duncan et al. (2007). The stratospheric chemical mechanism is taken from Douglass and Kawa (1999) and the polar stratospheric cloud parameterization is described in Considine et al. (2000).

The vertical range of the GMI 3-D CTM is from the ground up to approximately $80 \mathrm{~km}(0.015 \mathrm{hPa})$ and the model lacks some mesospheric processes, such as Lyman alpha photochemistry. Thus, the GMI 3-D CTM cannot be used to address the short-term influence of SPE-produced $\mathrm{HO}_{\mathrm{x}}$ and its impact on ozone in the middle and upper mesosphere. The GMI 3-D CTM will, therefore, be used in conjunction with the GSFC 2-D model to study the medium-term influence of the 2012 SPEs.

\subsection{Simulations of the GMI 3-D CTM}

The starting conditions for the two GMI 3-D CTM simulations used in this study were provided by a time dependent "spin-up" simulation from January 2004-December 2011, which included the appropriate source gas boundary conditions from WMO (2011) and the changing transport fields derived from MERRA for this time period. Two timedependent simulations, "C" and "D", were continued over the period 1 January through 31 December 2012. Simulation "C" included no SPEs and simulation "D" included all SPEs in this period.

\section{Short-term Influences of the SPEs}

A number of constituents have been observed and modeled to be modified by SPEs (e.g., López-Puertas et al., 2005a, b; von Clarmann et al., 2005; Verronen et al., 2006; Jackman et al., 2011; Damiani et al., 2012). We will focus on the SPE-caused impact on $\mathrm{HO}_{\mathrm{x}}, \mathrm{NO}_{\mathrm{x}}$, and ozone in this study. The SPEs can cause substantial increases in $\mathrm{HO}_{\mathrm{x}}$ and $\mathrm{NO}_{\mathrm{x}}$ constituents (see Sect. 3), which can directly impact ozone through catalytic destruction cycles (e.g., see Johnston and Podolske, 1978).

\subsection{Peroxy radical $\left(\mathrm{HO}_{2}\right)$}

The Aura Microwave Limb Sounder (MLS) measurement of the peroxy radical $\left(\mathrm{HO}_{2}\right)$ provides a direct observation and quantification of $\mathrm{HO}_{\mathrm{x}}$ changes due to the January $2012 \mathrm{SPE}$ in the middle atmosphere. Figure 3 (Top left) shows the daily average MLS $\mathrm{HO}_{2}$ changes from a five-day (18-22 January) average of $\mathrm{HO}_{2}$ measurements before the SPE period for the $60-82.5^{\circ} \mathrm{N}$ band. Enhancements of $>0.2 \mathrm{ppbv}$ are observed in the middle mesosphere over periods 23-26 January and 28-29 January. A peak of $>1 \mathrm{ppbv}$ is observed from $\sim 0.05-$ $0.1 \mathrm{hPa}$ on 24 January. These $\mathrm{HO}_{2}$ enhancements are slightly larger than those reported in Jackman et al. (2011) for the January 2005 SPEs.

The measurement of $\mathrm{HO}_{2}$ in the atmosphere by MLS is impressive given its relatively small abundance throughout the middle atmosphere, however, some care must be exercised in using these data. For example, MLS $\mathrm{HO}_{2}$ has a bias that is usually removed by taking day-night differences over the entire recommended pressure range. It was advantageous in this work to include all the MLS $\mathrm{HO}_{2}$ measurements to determine the SPE-caused impact. Removal of the five-day 
average before the SPE period, as done in this study, will also lead to a removal of the MLS $\mathrm{HO}_{2}$ bias assuming that the bias varies in only a minor way over a couple of weeks. Although the $\mathrm{MLS} \mathrm{HO}_{2}$ measurements are not recommended for scientific use above $0.046 \mathrm{hPa}$, those MLS observations are shown here to qualitatively indicate the morphology of the $\mathrm{HO}_{2}$ change during the disturbed periods.

We also show the daily average MLS $\mathrm{HO}_{2}$ changes from a five-day (18-22 January) average of $\mathrm{HO}_{2}$ measurements before the SPE period for the $60-82.5^{\circ} \mathrm{S}$ band in Fig. 3 (Top right). Note that the observed $\mathrm{SH} \mathrm{HO}_{2}$ enhancement is at a peak value of $>0.5 \mathrm{ppbv}$ for the $\sim 0.015-0.07 \mathrm{hPa}$ region on 24 January, which is less than the peak levels shown in the $\mathrm{NH}$ (see Fig. 3, Top left). The $\mathrm{HO}_{\mathrm{x}}$ produced by the SPE is approximately the same in both hemispheres, however, the lifetime of $\mathrm{HO}_{2}$ is diminished in the $\mathrm{SH}$ (summer) due to the higher background $\mathrm{HO}_{\mathrm{x}}$ level and a faster loss of $\mathrm{HO}_{2}$ at this time of year. The increased solar radiation in the $\mathrm{SH}$ (summer) leads to an increase in the amount of background mesospheric $\mathrm{HO}_{\mathrm{x}}$ by a factor of about 2-6 relative to the $\mathrm{NH}$, thus the loss of $\mathrm{HO}_{2}$ is larger in the $\mathrm{SH}$ through the increase in the rate of reactions

$\mathrm{OH}+\mathrm{HO}_{2} \rightarrow \mathrm{H}_{2} \mathrm{O}+\mathrm{O}_{2}$

and

$\mathrm{H}+\mathrm{HO}_{2} \rightarrow$ products

The GSFC 2-D model predicted $\mathrm{HO}_{2}$ change from the fiveday (18-22 January) average using simulation " $\mathrm{B}$ " is shown in Fig. 3 (Bottom plots) for the same period. Also, the MLS averaging kernel (AK) is applied to the model results. The variation with time and pressure as well as the magnitude of the computed change is fairly similar to the $\mathrm{MLS}^{\mathrm{HO}} \mathrm{O}_{2}$ observations, especially in the $\mathrm{NH}$. The predicted $\mathrm{HO}_{2}$ increase is slightly smaller than the observed increase due to the SPEs in the SH, however, the pressure levels impacted are fairly similar between the model and measured values. The predicted $\mathrm{HO}_{2}$ enhancements due to the SPEs are within the computed precision error $(\sim 0.4 \mathrm{ppbv}$ near $0.1 \mathrm{hPa})$ for daily average MLS measurements of $\mathrm{HO}_{2}$ in these latitude bands.

We also completed a similar analysis of the $\mathrm{HO}_{2}$ enhancements caused by the March 2012 SPEs. The $\mathrm{HO}_{2}$ changes from a five-day (2-6 March) average of $\mathrm{HO}_{2}$ measurements before the SPE period for the $60-82.5^{\circ} \mathrm{N}$ and $60-82.5^{\circ} \mathrm{S}$ bands were examined. We found MLS observed enhancements of $>0.2 \mathrm{ppbv}$ in the mesosphere over five days (7-11 March) with a peak of 0.8 ppbv occurring near $0.05 \mathrm{hPa}$ on 8 March in the NH and observed enhancements $>0.2 \mathrm{ppbv}$ on three days (7, 8, and 10 March), see Fig. 4 (Top left), and a peak of $0.4 \mathrm{ppbv}$ occurring near $0.05 \mathrm{hPa}$ on 8 March in the SH (Fig. 4, Top right).

The general location of the peaks and variations with pressure are fairly similar between the measurements and model predictions for $\mathrm{HO}_{2}$ in early March 2012 during the SPE,

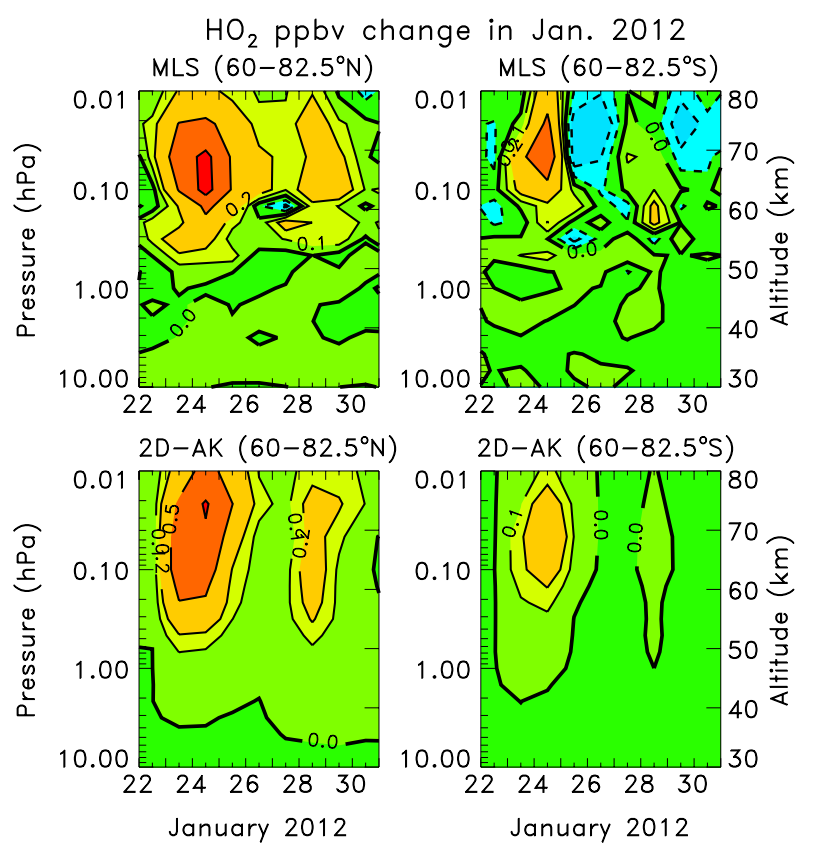

Fig. 3. Daily averaged $\mathrm{HO}_{2}$ changes from Aura MLS measurements (Top) and GSFC 2-D model predictions (Bottom) for the $60-82.5^{\circ} \mathrm{N}$ band (left plots) and $60-82.5^{\circ} \mathrm{S}$ band (right plots). An average observed (predicted) $\mathrm{HO}_{2}$ profile for the period 18-22 January 2012 was subtracted from the observed (predicted) $\mathrm{HO}_{2}$ values for the plotted days of 22-30 January 2012. The contour intervals for the $\mathrm{HO}_{2}$ differences are $-0.2,-0.1,0.0,0.1,0.2,0.5$, and $1 \mathrm{ppbv}$. The MLS averaging kernel (AK) was used to sample the model results.

however, there are some differences in the peak values (see Fig. 4, Bottom plots). The predicted $\mathrm{HO}_{2}$ change as a result of the March 2012 SPE shows a peak on 8 March near 0.02 to $0.05 \mathrm{hPa}$ of about $1 \mathrm{ppbv}$ for latitude band $60-82.5^{\circ} \mathrm{N}$ and a peak of about $0.7 \mathrm{ppbv}$ for latitude band $60-82.5^{\circ} \mathrm{S}$. The solar radiation is slightly larger in the $\mathrm{SH}$ compared to the $\mathrm{NH}$ polar region in early March. Also, more mesospheric $\mathrm{H}_{2} \mathrm{O}$ is present in the SH compared to the NH due to the upward motion during the southern polar summer transporting up $\mathrm{H}_{2} \mathrm{O}$ from the upper stratospheric water source. These two factors lead to a larger background concentration of $\mathrm{HO}_{\mathrm{x}}$ constituents in the SH and thus a larger loss of the SPE-produced $\mathrm{HO}_{2}$ through $\mathrm{R} 1$ and $\mathrm{R} 2$ and a slightly smaller peak of $\mathrm{HO}_{2}$ in the $\mathrm{SH}$ compared to the $\mathrm{NH}$.

\subsection{Ozone}

The $\mathrm{HO}_{\mathrm{x}}$ constituents are the primary cause of ozone depletion in the mesosphere during SPEs and the impact during the January and March 2012 SPE periods is seen clearly in the MLS ozone measurements. Several catalytic $\mathrm{HO}_{\mathrm{x}}$ cycles are important in the middle atmosphere, however, the process

$\mathrm{H}+\mathrm{O}_{3} \rightarrow \mathrm{OH}+\mathrm{O}_{2}$ 


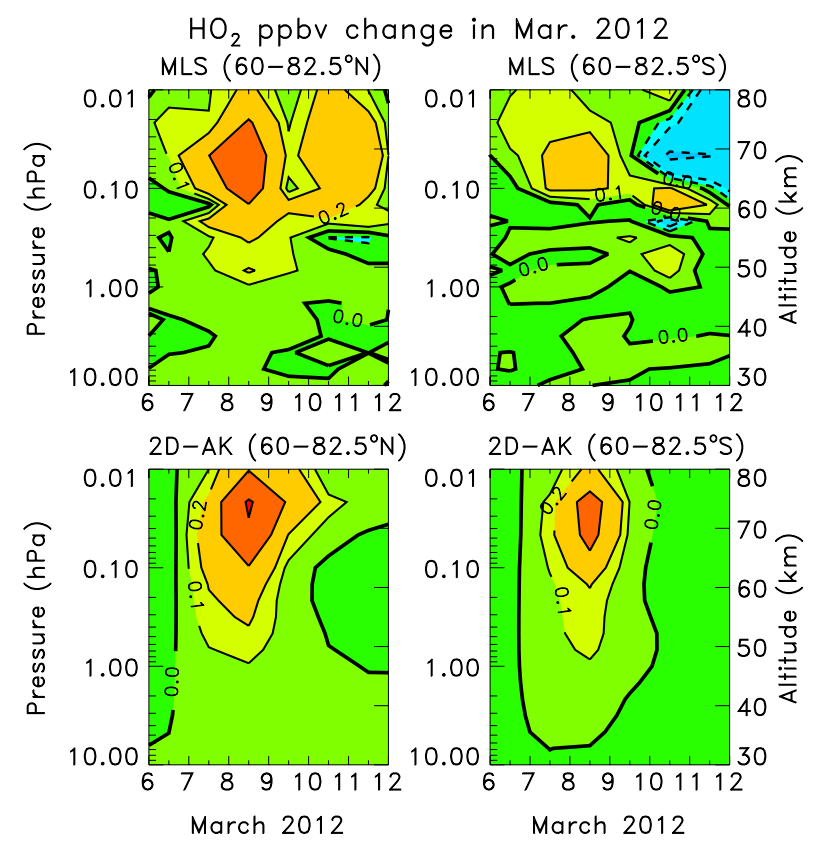

Fig. 4. Daily averaged $\mathrm{HO}_{2}$ changes from Aura MLS measurements (Top) and GSFC 2-D model predictions (Bottom) for the $60-82.5^{\circ} \mathrm{N}$ band (left plots) and $60-82.5^{\circ} \mathrm{S}$ band (right plots). An average observed (predicted) $\mathrm{HO}_{2}$ profile for the period 2-6 March 2012 was subtracted from the observed (predicted) $\mathrm{HO}_{2}$ values for the plotted days of 6-11 March 2012. The contour intervals for the $\mathrm{HO}_{2}$ differences are $-0.5,-0.2,-0.1,0.0,0.1,0.2,0.5$, and 1 ppbv. The MLS averaging kernel (AK) was used to sample the model results.

followed by

$\mathrm{OH}+\mathrm{O} \rightarrow \mathrm{H}+\mathrm{O}_{2}$

Net: $\mathrm{O}+\mathrm{O}_{3} \rightarrow 2 \mathrm{O}_{2}$

is dominant throughout much of the mesosphere. During strong SPEs, such as these in 2012, the $\mathrm{HO}_{\mathrm{x}}$ catalytic cycle

$\mathrm{OH}+\mathrm{O}_{3} \rightarrow \mathrm{HO}_{2}+\mathrm{O}_{2}$

followed by

$\mathrm{HO}_{2}+\mathrm{O} \rightarrow \mathrm{OH}+\mathrm{O}_{2}$

Net: $\mathrm{O}+\mathrm{O}_{3} \rightarrow 2 \mathrm{O}_{2}$

also contributes significantly to the ozone decrease.

We show the MLS daily average ozone change from a five-day (18-22 January) average of ozone measurements before the SPE period for the $60-82.5^{\circ} \mathrm{N}$ band in Fig. 5 (Top left). Ozone depletions of $>20 \%$ are observed in the middle mesosphere for the $60-82.5^{\circ} \mathrm{N}$ band over the 24-27 January period with a maximum of $60 \%$ depletion occurring near 0.02-0.05 hPa on 25 January (Fig. 5, Top left). The $\mathrm{HO}_{\mathrm{x}}$ constituents have a relatively short lifetime $(\sim$ hours $)$ throughout most of the mesosphere (below $\sim 80 \mathrm{~km}$, see Pickett et al., 2006), however, they can cause very large ozone depletion,

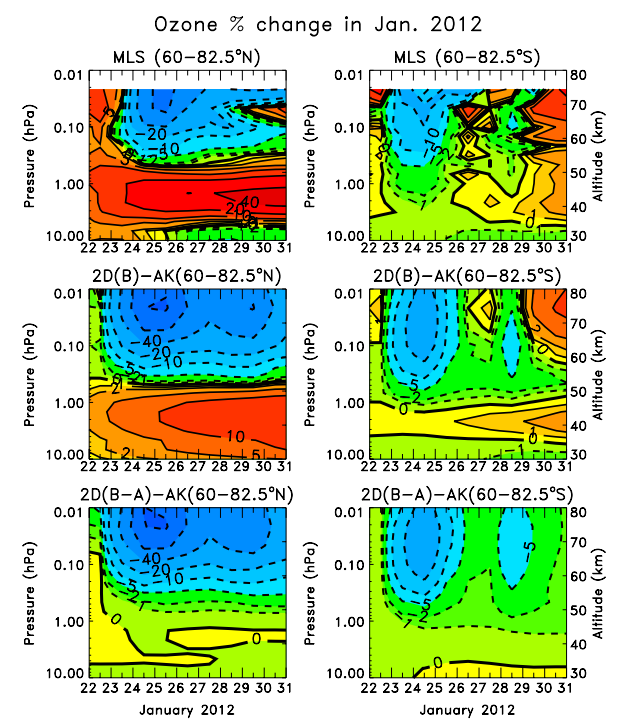

Fig. 5. Daily averaged ozone changes from Aura MLS measurements (Top) and GSFC 2-D model predictions (Middle, Bottom) for the $60-82.5^{\circ} \mathrm{N}$ band (left plots) and the $60-82.5^{\circ} \mathrm{S}$ band (right plots). An average observed (predicted) ozone profile for the period 18-22 January 2012 was subtracted from the observed (predicted) ozone values for the plotted days of 22-30 January 2012 for Aura MLS measurements (Top) and for the GSFC 2-D model simulation "B (with SPEs)" (Middle). The Bottom plot shows the difference between GSFC 2-D model simulations "B (with SPEs)" and "A (without SPEs)." The contour intervals for the ozone differences are -80 , $-60,-40,-20,-10,-5,-2,-1,0,1,2,5,10,20$, and $40 \%$. The MLS averaging kernel (AK) was used to sample the model results.

which has also been observed in other very large substantial SPEs (e.g., Solomon et al., 1983; Jackman et al., 2001, 2011; Verronen et al., 2006).

Surprisingly, the MLS observations show an increase in ozone at their retrieval level of $0.046 \mathrm{hPa}$ for 28-30 January, with ozone decreases above and below. It is unclear what causes this MLS-observed ozone increase at the $0.046 \mathrm{hPa}$ level during this period. MIPAS ozone measurements at this same time period and location also show this behavior (von Clarmann et al., 2013). The observed ozone increases at pressures greater than $0.5 \mathrm{hPa}$ are caused by seasonal changes ongoing at this time of year, which mitigate and overwhelm the SPE-caused ozone decrease.

We show two model computations of the SPE-caused predicted ozone change in Fig. 5 (Middle and Bottom left). The model predicted changes in Fig. 5 (Middle left) are derived in the same manner as the MLS observed changes, wherein the modeled ozone in simulation " $\mathrm{B}$ " is subtracted from the fiveday (18-22 January) average of modeled ozone before the SPE period. Thus, this model predicted change will also have seasonal variations included. The model predicted changes for Fig. 5 (Bottom left) are derived by subtracting simulation "A" from simulation "B" to produce a SPE-only caused ozone change thereby removing the seasonal ozone increase 
in the upper stratosphere. As in Figs. 3 and 4, the MLS averaging kernel (AK) is applied to the model results. Note that there are some differences between the measurements and model predictions (see Fig. 5, Top and Middle left). For example, although both the measurements and model predictions indicate a SPE-caused ozone depletion in the middle mesosphere over the 24-27 January period, the model predicts a somewhat larger altitude range of predicted ozone decrease from the SPEs as well as a smaller seasonal increase in the upper stratosphere and lower mesosphere.

As in Fig. 5 (Top left), we show the MLS daily average ozone change from a five-day (18-22 January) average of ozone measurements before the SPE period for the $60-82.5^{\circ} \mathrm{S}$ band in Fig. 5 (Top right). Ozone depletions of $>10 \%$ are observed in the middle mesosphere for the 60 $82.5^{\circ} \mathrm{S}$ band over the 23-24 January period with a maximum of $30 \%$ depletion occurring near $0.02 \mathrm{hPa}$ on 23 January. A small depletion from about $2-0.04 \mathrm{hPa}$ is even observed on 28 January as a result of the second SPE in January. These SPE-caused ozone depletions are less in the polar SH (compared to the polar $\mathrm{NH}$, left plots) due to the shorter lifetime of $\mathrm{HO}_{\mathrm{x}}$ (and ultimate $\mathrm{HO}_{\mathrm{x}}$ influence) in the summer relative to the winter (e.g., see Solomon et al., 1983; Jackman et al., 2008).

We show two computations of the SPE-caused predicted ozone change for the $60-82.5^{\circ} \mathrm{S}$ band in Fig. 5 (Middle and Bottom right), derived in the same way as the model predictions in Fig. 5 (Middle and Bottom left). The model predicted ozone change is in reasonable agreement with the observed MLS ozone changes on 23-24 January, both in the magnitude and timing. The model predicted changes shown in Fig. 5 (Bottom right), derived by subtracting simulation " $\mathrm{A}$ " from "B", indicate that seasonal increases in ozone are important in the upper stratosphere $(\sim 1-6 \mathrm{hPa})$ and above $0.2 \mathrm{hPa}$ on 29-31 January.

Given the somewhat surprising MLS observations of an increase in ozone at the retrieval level of $0.046 \mathrm{hPa}$ in the 60 $82.5^{\circ} \mathrm{N}$ band for the SPE on 28-30 January (see Fig. 5, Top left), we show the MLS observations during the March 2012 SPE period for this same region in Fig. 6 (Top left). Clearly, MLS measured mesospheric ozone is being depleted at all levels as a result of the SPE. The model results given in Fig. 6 (Middle and Bottom left), computed in the same way as in Fig. 5, also show ozone being depleted throughout the mesosphere. Both measurements and model results show ozone decreases $>60 \%$ on $8-9$ March at about $0.05-0.02 \mathrm{hPa}$. The measurements and model simulations also indicate a modest seasonally-driven ozone increase in the upper stratosphere. As an aside, MIPAS observations show similar ozone depletion due to the March 2012 SPE.

We also examined the MLS ozone observations as well as our model predictions for the $60-82.5^{\circ} \mathrm{S}$ band during the March 2012 SPE period (see Fig. 6, Top right). The measurements and model results indicate significant ozone depletion as a result of the SPE with both showing ozone de-

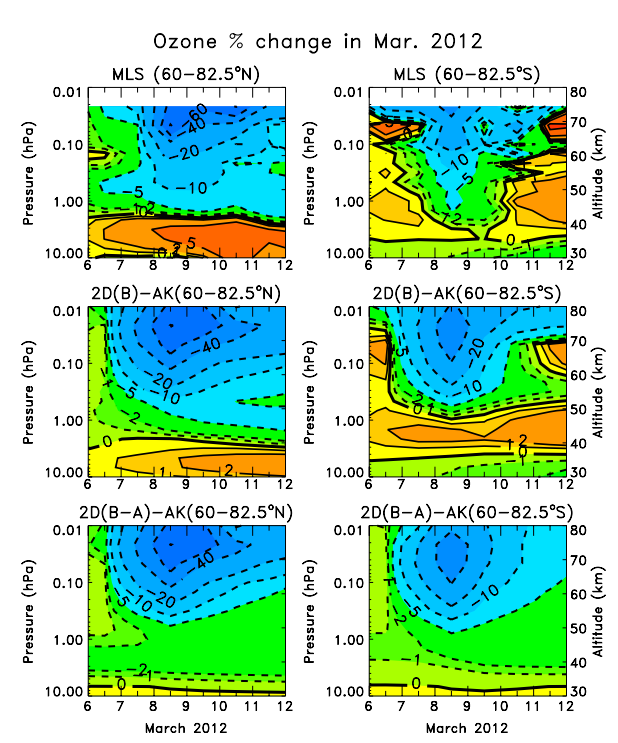

Fig. 6. Daily averaged ozone changes from Aura MLS measurements (Top) and GSFC 2-D model predictions (Middle, Bottom) for the $60-82.5^{\circ} \mathrm{N}$ band (left plots) and for the $60-82.5^{\circ} \mathrm{S}$ band (right plots). An average observed (predicted) ozone profile for the period 2-6 March 2012 was subtracted from the observed (predicted) ozone values for the plotted days of 6-11 March 2012 for Aura MLS measurements (Top) and for the GSFC 2-D model simulation "B (with SPEs)" (Middle). The Bottom plot shows the difference between GSFC 2-D model simulations "B (with SPEs)" and "A (without SPEs)." The contour intervals for the ozone differences are -80 , $-60,-40,-20,-10,-5,-2,-1,0,1,2,5$, and $10 \%$. The MLS averaging kernel (AK) was used to sample the model results.

creases $>20 \%$ on 8 March through the middle mesosphere. The model predictions given in Fig. 6 (Middle and Bottom right) do indicate a somewhat larger ozone depletion for the 7-11 March period, when compared to the MLS measurements.

\subsection{Nitrogen oxides, $\mathrm{NO}_{\mathrm{x}}\left(\mathrm{NO}+\mathrm{NO}_{2}\right)$}

ACE-FTS (hereinafter referred to as ACE) (Bernath et al., 2005) and MIPAS (Fischer et al., 2008) measured both NO and $\mathrm{NO}_{2}$ (e.g., Rinsland et al., 2005; López-Puertas et al., 2005a). We defined $\mathrm{NO}_{\mathrm{x}}$ in Sect. 1 as $\mathrm{N}+\mathrm{NO}+\mathrm{NO}_{2}$, but here we identify $\mathrm{NO}_{\mathrm{x}}$ as approximated by $\mathrm{NO}+\mathrm{NO}_{2}$ since $\mathrm{N}$ is minuscule in the middle atmosphere.

ACE provided $\mathrm{NO}+\mathrm{NO}_{2}$ profile measurements at fairly high latitudes during the January through April 2012 period. For example, for the period Days of Year (DoY) 22-47 (22 January to 16 February) ACE observations were made in the $\mathrm{NH}$ between about 65 and $68^{\circ} \mathrm{N}$. The ACE measured $\mathrm{NO}_{\mathrm{x}}$ changes from DoY 22 (22 January) are shown in Fig. 7a. Large increases (>100 ppbv) are observed in the middle to upper mesosphere $(<0.05 \mathrm{hPa})$ for DoY 24-36. Some of these increases are certainly due to the solar protons and associated secondary electrons, however, energetic electron 


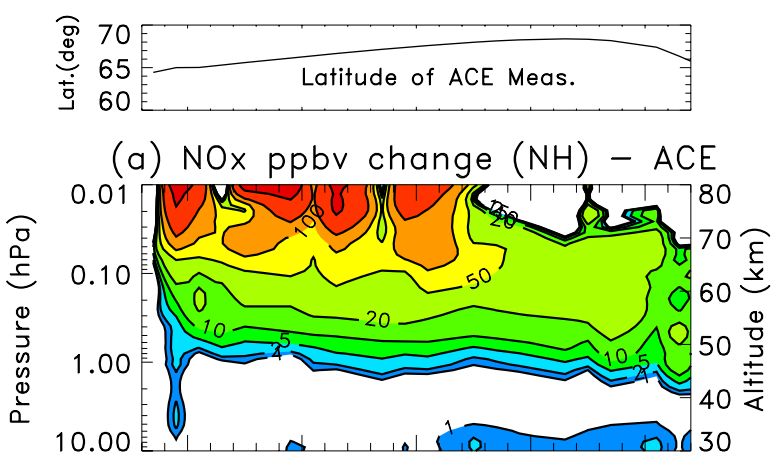

(b) NOx ppbv change $\left(65-68^{\circ} \mathrm{N}\right)$ - MIPAS

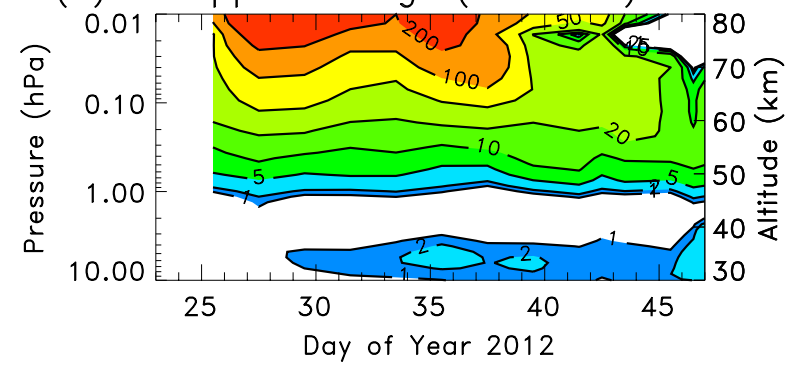

Fig. 7. Daily averaged $\mathrm{NO}_{\mathrm{x}}\left(\mathrm{NO}+\mathrm{NO}_{2}\right)$ changes from Day of Year (DoY) 22 (22 January) 2012 values as measured by ACE (a) and MIPAS $\left(65-68^{\circ} \mathrm{N}\right)(\mathbf{b})$. The contour intervals for the $\mathrm{NO}_{\mathrm{x}}$ differences are 1, 2, 5, 10, 20, 50, 100, 200, and 500 ppbv. The northern polar latitudes of ACE measurements are given in the Top plot.

precipitation (EEP) may also be contributing in the middle and upper mesosphere (pressures $<0.1 \mathrm{hPa}$ ). The solar protons penetrate deeper into the atmosphere than the EEP, and cause most of the measured enhanced $\mathrm{NO}_{\mathrm{x}}$ in the lower mesosphere.

Substantial increases (> 20 ppbv) were observed throughout most of the mesosphere for these same days continuing through Day of Year 44 for the lower mesosphere $(\sim 0.04$ $0.7 \mathrm{hPa}$ ). MIPAS measurements are also available during this time period, but not for every day, and are given in Fig. 7b. It should be noted that the MIPAS nominal observations used here are limited to tangent heights of $70 \mathrm{~km}$. Hence, the retrieved $\mathrm{NO}_{\mathrm{x}}$ profiles have little-to-no vertical resolution above $70 \mathrm{~km}$. In the $\mathrm{SH}$, MIPAS $\mathrm{NO}_{\mathrm{x}}$ might be underestimated (due to the effect of the a priori profile shape) even down to $65 \mathrm{~km}$.

In spite of these important caveats, the MIPAS measurements are generally in agreement with ACE when the slightly larger averaging kernels of MIPAS are taken into account. Such measured $\mathrm{NO}_{\mathrm{x}}$ enhancements were similar to those observed by ACE as a result of the January 2005 SPEs (Jackman et al., 2011).

ACE also takes measurements at high southern latitudes, however, the number of days of observations is relatively limited and will not be shown. A comparison of the SPEcaused $\mathrm{NO}_{\mathrm{x}}$ enhancement over a larger polar region $\left(60-90^{\circ}\right)$ is shown in Fig. 8 for the NH (Top left) and SH (Top right),

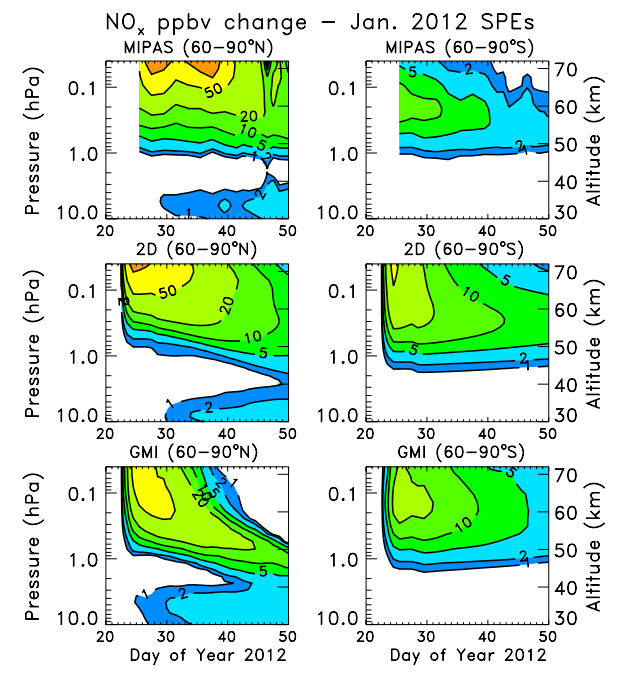

Fig. 8. Daily averaged $\mathrm{NO}_{\mathrm{x}}\left(\mathrm{NO}+\mathrm{NO}_{2}\right)$ changes from DoY 22 (22 January) 2012 values for $60-90^{\circ} \mathrm{N}$ (left plots) and $60-90^{\circ} \mathrm{S}$ (right plots) as measured by MIPAS (Top) and calculated by the GSFC 2-D model (Middle) and the GMI 3-D CTM (Bottom). The contour intervals for the $\mathrm{NO}_{\mathrm{X}}$ differences are $1,2,5,10,20,50$, and 100 ppbv.

respectively, for the MIPAS instrument and the GSFC 2-D model (Middle plots) and the GMI 3-D CTM (Bottom plots). The GMI 3-D CTM results are most reliable at pressures greater than $0.04 \mathrm{hPa}$, thus all plots in Fig. 8 are only shown up to this level. The models indicate a somewhat smaller $\mathrm{NO}_{\mathrm{x}}$ change in the $\mathrm{NH}$ and a somewhat larger $\mathrm{NO}_{\mathrm{x}}$ change in the $\mathrm{SH}$, compared with MIPAS observations. The smaller predicted $\mathrm{NO}_{\mathrm{x}}$ change in the $\mathrm{NH}$ may be related to the absence of concurrent energetic electron precipitation in our computations.

As an aside, it is difficult to include the EEP contribution in our computations during the time period of the SPEs. The NOAA MEPED instrument's electron energy channels are contaminated by protons, thus any measurements of EEP during SPEs is questionable (e.g., p. 2 of Verronen et al., 2011a; Table 3 of Yando et al., 2011).

Although similar, there are some differences between the two model predictions of the enhanced $\mathrm{NO}_{\mathrm{x}}$ evolution. The GMI 3-D CTM holds the SPE-caused $\mathrm{NO}_{\mathrm{x}}$ increases closer to the NH pole (Fig. 8, Bottom left) and transports a larger amount of $\mathrm{NO}_{\mathrm{x}}$ to the stratosphere than indicated in the GSFC 2-D model (Fig. 8, Middle left) or observed in MIPAS data (Fig. 8, Top left). In contrast, the GSFC 2-D model appears to conserve $\mathrm{NO}_{\mathrm{x}}$ over a longer period of time in the SH polar region than indicated in the GMI 3-D CTM (Fig. 8, Middle and Bottom right).

We turn our attention to the March 2012 SPE period in Fig. 9. The ACE and MIPAS measured $\mathrm{NO}_{\mathrm{x}}$ ppbv change from 6 March is shown in Fig. 9a, b and indicates enhancements of over $20 \mathrm{ppbv}$ throughout most of the northern polar 

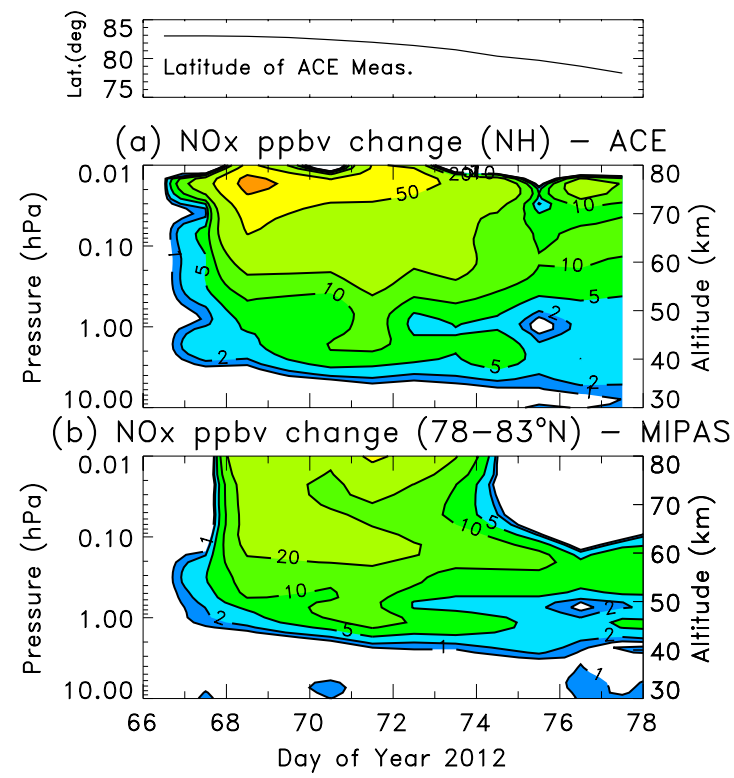

Fig. 9. Daily averaged $\mathrm{NO}_{\mathrm{x}}\left(\mathrm{NO}+\mathrm{NO}_{2}\right)$ changes from DoY 66 (6 March) 2012 values as measured by ACE (a) and MIPAS (78$\left.83^{\circ} \mathrm{N}\right)(\mathbf{b})$. The contour intervals for the $\mathrm{NO}_{\mathrm{x}}$ differences are 1,2 , $5,10,20,50$, and $100 \mathrm{ppbv}$. The northern polar latitudes of ACE measurements are given in the Top plot.

mesosphere for several days (DoY 68-74 for ACE and DoY 68-72 for MIPAS) as a result of this SPE period. Peak $\mathrm{NO}_{\mathrm{x}}$ increases over $100 \mathrm{ppbv}$ were observed by ACE on DoY 68 (8 March) between 0.01 and $0.02 \mathrm{hPa}$ as a result of the March 2012 SPE.

As during the January 2012 SPE period, ACE also takes measurements at high southern latitudes. Again, however, the number of days of observations is relatively limited and will not be shown. A comparison of the SPE-caused $\mathrm{NO}_{\mathrm{x}}$ enhancement over a larger polar region $\left(60-90^{\circ}\right)$ is shown in Fig. 10 for the NH (Top left) and SH (Top right), respectively, for the MIPAS instrument and the GSFC 2-D model (Middle plots) and the GMI 3-D CTM (Bottom plots). Although the impacted altitudes are similar between the measurements and the model predictions, the models indicate a somewhat larger $\mathrm{NO}_{\mathrm{x}}$ change in both hemispheres, when compared with MIPAS observations. Some of this larger model predicted SPEcaused $\mathrm{NO}_{\mathrm{y}}$ enhancement can be explained by the finer vertical grid of the model (1-2 km in the mesosphere) compared to the MIPAS vertical field-of-view of about $3 \mathrm{~km}$ (LópezPuertas et al., 2005a). As for January (see Fig. 8), the GMI 3-D CTM transports a larger amount of $\mathrm{NO}_{\mathrm{x}}$ to the polar NH stratosphere (Fig. 10, Bottom left) than indicated in the GSFC 2-D model (Fig. 10, Middle left). The models show generally similar $\mathrm{NO}_{\mathrm{x}}$ transport to the stratosphere in the $\mathrm{SH}$ (Middle and Bottom right).

Both models predict that the initial $\mathrm{NO}_{\mathrm{x}}$ enhancement is substantially larger than the measured enhancements, with peak increases greater than 50 ppbv on DoY 68-69 in the up-

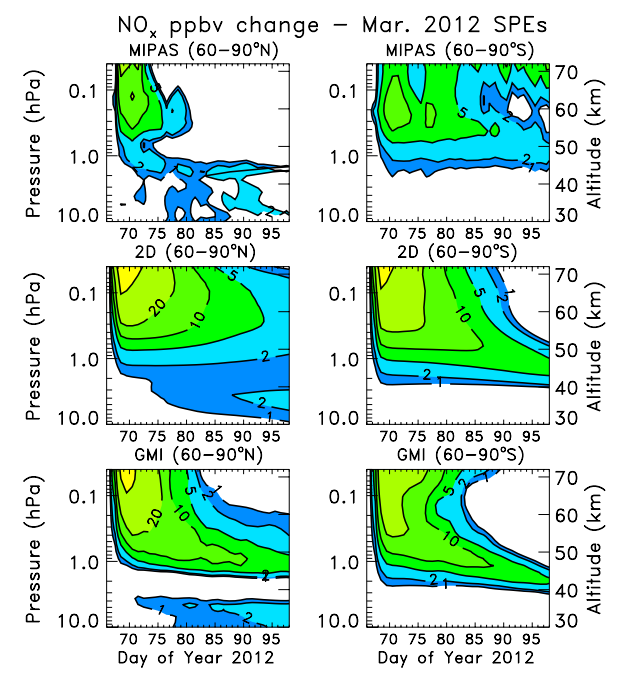

Fig. 10. Daily averaged $\mathrm{NO}_{\mathrm{x}}\left(\mathrm{NO}+\mathrm{NO}_{2}\right)$ changes from DoY 66 (6 March) 2012 values for 60-90 $\mathrm{N}$ (left plots) and 60-90 $\mathrm{S}$ (right plots) as measured by MIPAS (Top) and calculated by the GSFC 2-D model (Middle) and the GMI 3-D CTM (Bottom). The contour intervals for the $\mathrm{NO}_{\mathrm{x}}$ differences are 1, 2, 5, 10, 20, and $50 \mathrm{ppbv}$.

per mesosphere for both hemispheres, compared with peak MIPAS measured increases of only about 25 ppbv (Fig. 10, left). Note also that both models predicted $\mathrm{NO}_{\mathrm{x}}$ changes in the NH on DoY 76-80 showing > 5 ppbv throughout most of the mesosphere (pressures $<0.5 \mathrm{hPa}$ ) whereas the MIPAS measured $\mathrm{NO}_{\mathrm{x}}$ changes are $<5 \mathrm{ppbv}$ in the same region (Fig. 10, left). MIPAS measured mesospheric $\mathrm{NO}_{\mathrm{x}}$ enhancements are gone by DoY 81, however, model predicted $\mathrm{NO}_{\mathrm{x}}$ increases continue and gradually diminish in the lower mesosphere through DoY 97. The disappearance of NH MIPAS $\mathrm{NO}_{\mathrm{x}}$ enhancements is possibly related to a polar vortex rupture and release of mesospheric $\mathrm{NO}_{\mathrm{x}}$ towards mid latitudes, which appears in MIPAS $\mathrm{CH}_{4}$ data (not shown). Both models used transport from MERRA for the year 2012. However, since observational information in the mesosphere is limited there may be dynamical differences between the atmosphere and the models for the mesosphere. The models likely underestimate the amount of high latitude mesospheric $\mathrm{NO}_{\mathrm{x}}$ transported to lower latitudes.

The model predicted $\mathrm{NO}_{\mathrm{x}}$ changes in the $\mathrm{SH}$ on DoY 7680 are $\sim 5-20$ ppbv throughout the middle to lower mesosphere $(\sim 0.03-0.7 \mathrm{hPa})$, which are in reasonable agreement with the MIPAS measurements during this time period (Fig. 10, right). In the upper stratosphere $(\sim 1-3 \mathrm{hPa})$ somewhat more SPE-produced $\mathrm{NO}_{\mathrm{x}}$ is simulated in the models than observed. Thus, the models predict a more substantial SPE-caused $\mathrm{NO}_{\mathrm{x}}$ perturbation in the $\mathrm{SH}$, than indicated in the measurements, which will then cause a larger impact on stratospheric ozone.

Overall both models predict $\mathrm{NO}_{\mathrm{x}}$ enhancements which are larger than the MIPAS observations in both hemispheres 
for the March 2012 SPE. Neither model includes ion chemistry, thus both models will predict a smaller enhancement of $\mathrm{HNO}_{3}$ (and subsequent reduction in $\mathrm{NO}_{\mathrm{x}}$ ) due to the SPEs. This repartitioning through ion chemistry of $\mathrm{NO}_{\mathrm{x}}$ to $\mathrm{HNO}_{3}$ has been found to be an important process (see LópezPuertas et al., 2005b; Verronen et al., 2008, 2011b) and may be responsible for the loss of up to a few ppbv of $\mathrm{NO}_{\mathrm{x}}$ to $\mathrm{HNO}_{3}$ in the lower mesosphere. This process is unlikely to explain the large differences between MIPAS and the models for $\mathrm{NO}_{\mathrm{x}}$ above $\sim 0.1 \mathrm{hPa}$, but may reduce these discrepancies in the lower mesosphere. Also, the proton flux source for the March 2012 SPE is the same as that for the January 2012 SPE (GOES 13), thus this $\mathrm{NO}_{\mathrm{x}}$ over-prediction above $\sim 0.1 \mathrm{hPa}$ is not easily explained. Further model-measurement comparisons of these SPE-caused impacts will be needed to help understand this disagreement.

\section{Medium-term Influences of the SPEs: odd nitrogen $\left(\mathrm{NO}_{\mathrm{y}}\right)$ and ozone changes}

The last two figures (Figs. 11-12) show only GSFC 2D model and GMI 3-D CTM predicted medium-term ( months) influences of the SPE for all of 2012. These plots were derived by subtracting the simulations without the SPEs ("A" for the GSFC 2-D model; "C" for the GMI 3-D CTM) from the simulations with the SPEs ("B" for the GSFC 2-D model and "D" for the GMI 3-D CTM) to produce a SPEonly caused impact.

The $\mathrm{NO}_{\mathrm{x}}$ family rapidly converts in the stratosphere to other constituents in the odd nitrogen group $\left(\mathrm{NO}_{\mathrm{y}}=\mathrm{N}\left({ }^{4} \mathrm{~S}\right)\right.$ $+\mathrm{N}\left({ }^{2} \mathrm{D}\right)+\mathrm{NO}+\mathrm{NO}_{2}+\mathrm{NO}_{3}+2 \mathrm{~N}_{2} \mathrm{O}_{5}+\mathrm{HNO}_{2}+\mathrm{HNO}_{3}+$ $\mathrm{HO}_{2} \mathrm{NO}_{2}+\mathrm{ClONO}_{2}+\mathrm{BrONO}_{2}$ ). The SPE-caused $\mathrm{NO}_{\mathrm{y}}$ ppbv enhancement and ozone percentage changes are given in Figs. 11 and 12 for the polar $\left(60-90^{\circ}\right) \mathrm{NH}$ and SH, respectively. $\mathrm{NO}_{\mathrm{y}}$ enhancements exceeding 2 ppbv are computed in the polar NH for much of the first five months of the year (J-F-M-A-M) throughout most of the mesosphere and part of the upper stratosphere in the GSFC 2-D model (Fig. 11, Top left). The GMI 3-D CTM predictes a greater impact by the 2012 SPEs on $\mathrm{NO}_{\mathrm{y}}$ in the polar NH (Fig. 11, Top right). Much more $\mathrm{NO}_{\mathrm{y}}$ is transported to the stratosphere from the mesosphere by the GMI 3-D CTM compared with the GSFC 2-D model in the J-F-M time period. Some of that $\mathrm{NO}_{\mathrm{y}}$ enhancement computed by the GMI 3-D CTM is diminished over the spring and summer, however, levels of $\mathrm{NO}_{\mathrm{y}}>2 \mathrm{ppbv}$ are observed for much of the year in the upper stratosphere (Fig. 11, Top right).

Large computed NH ozone decreases (> $20 \%$, dark blue colors) during and shortly after the two SPE periods (January and March) in the mesosphere were primarily caused by the SPE-produced $\mathrm{HO}_{\mathrm{x}}$ increases (Fig. 11, Bottom plots). The GSFC 2-D model predicted upper stratospheric ozone decreases of $2-4 \%$ (Fig. 11, Bottom left) and the GMI 3-D CTM predicted upper ozone decreases of 5-13\% (Fig. 11,

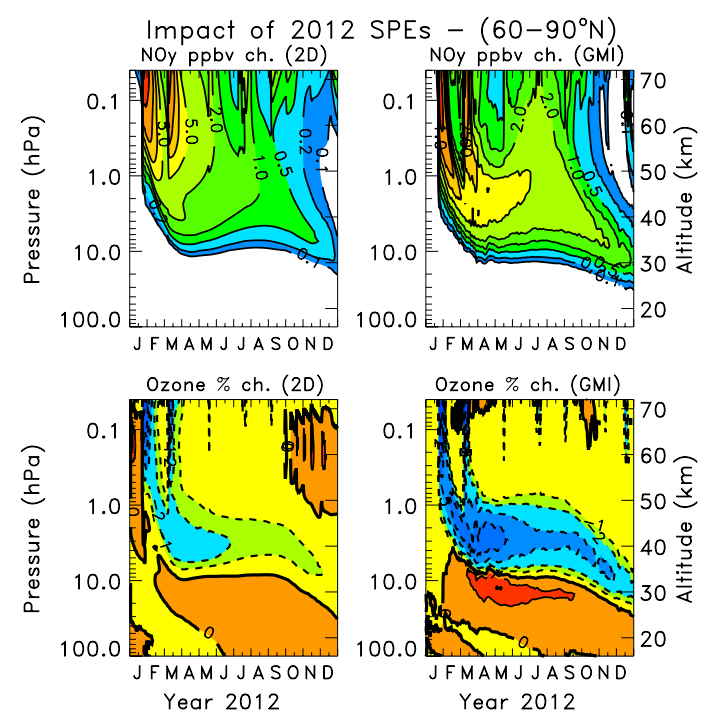

Fig. 11. (Left) Difference between GSFC 2-D model simulation "B (with SPEs)" and "A (without SPEs)". (Right) Difference between GMI 3-D CTM simulation "D (with SPEs)" and "C (without SPEs)". $\mathrm{NO}_{\mathrm{y}}$ (Top) and Ozone (Bottom) for $60-90^{\circ} \mathrm{N}$ are given for all months of 2012. The contour intervals for the $\mathrm{NO}_{\mathrm{y}}$ differences are $0.1,0.2,0.5,1,2,5,10,20$, and $50 \mathrm{ppbv}$. The contour intervals for the Ozone differences are $-20,-10,-5,-2,-1,0,1$, and $2 \%$.

Bottom right). These differences in model predicted ozone depletions were caused by the somewhat larger transported $\mathrm{NO}_{\mathrm{y}}$ to the stratosphere given by the GMI 3-D CTM compared with the GSFC 2-D model (Fig. 11, Top plots).

The primary catalytic cycle for $\mathrm{NO}_{\mathrm{y}}$ destruction of ozone is:

$\mathrm{NO}+\mathrm{O}_{3} \rightarrow \mathrm{NO}_{2}+\mathrm{O}_{2}$

followed by

$\mathrm{NO}_{2}+\mathrm{O} \rightarrow \mathrm{NO}+\mathrm{O}_{2}$

Net: $\mathrm{O}+\mathrm{O}_{3} \rightarrow 2 \mathrm{O}_{2}$.

There is a region of predicted enhanced ozone due to the SPEs in the middle to lower stratosphere (especially, see Fig. 11, Bottom right). The GMI 3-D CTM shows increased ozone of $1-2 \%$ caused by the enhanced SPE-produced $\mathrm{NO}_{\mathrm{y}}$ sequestering chlorine and bromine into reservoir species $\left(\mathrm{ClONO}_{2}\right.$ and $\left.\mathrm{BrONO}_{2}\right)$. This reduces ozone depletion due to halogens in this region of the stratosphere. This mechanism ultimately leads to increased ozone in a portion of the middle and lower stratosphere and has been discussed before in relation to SPE impacts (e.g., see Jackman et al., 2009).

The computed January-February $\mathrm{NO}_{\mathrm{y}}$ enhancements are not as substantial in the polar SH (Fig. 12) as in the polar $\mathrm{NH}$ due to considerable loss of odd nitrogen in the intense sunlight of SH summer and early fall. The reactions most important for this loss are:

$\mathrm{NO}+h v(<191 \mathrm{~nm}) \rightarrow \mathrm{N}+\mathrm{O}$ 


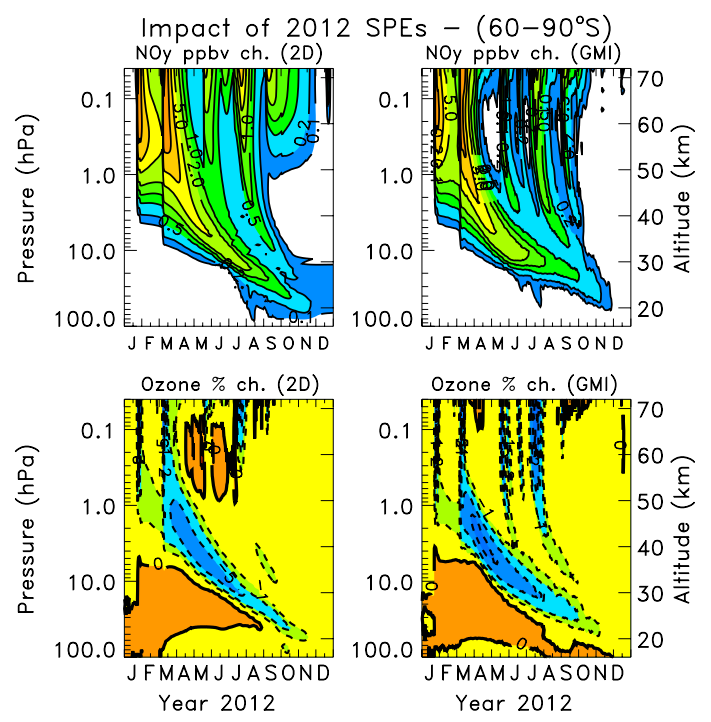

Fig. 12. (Left) Difference between GSFC 2-D model simulation "B (with SPEs)" and "A (without SPEs)". (Right) Difference between GMI 3-D CTM simulation "D (with SPEs)" and "C (without SPEs)". $\mathrm{NO}_{\mathrm{y}}$ (Top) and Ozone (Bottom) for $60-90^{\circ} \mathrm{S}$ are given for all months of 2012. The contour intervals for the $\mathrm{NO}_{\mathrm{y}}$ differences are $0.1,0.2,0.5,1,2,5,10$, and $20 \mathrm{ppbv}$. The contour intervals for the Ozone differences are $-20,-10,-5,-2,-1$, and $0 \%$.

followed by

$\mathrm{N}+\mathrm{NO} \rightarrow \mathrm{N}_{2}+\mathrm{O}$.

The winds are also generally upwards in the $\mathrm{SH}$ upper stratosphere in January and February, thus $\mathrm{NO}_{\mathrm{y}}$ constituents are transported upwards to the higher altitudes, where the loss process is greater. The vertical wind direction starts to reverse direction in early March and by late March is basically downwards (Fig. 12, Top plots). The wind reversal drags much more $\mathrm{NO}_{\mathrm{y}}$ from the mesosphere to the upper stratosphere by late May (Fig. 12, Top plots) leading to $\mathrm{NO}_{\mathrm{y}}$ enhancements $>2$ ppbv and associated ozone depletion of 5-8\% (GSFC 2D model) and 5-11\% (GMI 3-D CTM). $\mathrm{NO}_{\mathrm{y}}$ enhancements of $>0.2 \mathrm{ppbv}$ and the associated ozone decreases of $>1 \%$ descend through the winter and spring, reaching about $50 \mathrm{hPa}$ by November in both models. The predicted ozone depletion in the SH can be thought of as an "upper limit" given that the predicted SPE-caused $\mathrm{NO}_{\mathrm{x}}$ increases were somewhat higher than the measured SPE-caused $\mathrm{NO}_{\mathrm{x}}$ increases (see Fig. 10, Right). Note, also, that there were other SPE periods in May, June, July, September, October, November, and December, which are seen in the enhanced $\mathrm{NO}_{\mathrm{y}}$ in both hemispheres (Figs. 11 and 12, Top panels). These particular SPE periods were not as large as those that occurred in January and March.

The impact of the 2012 SPEs on total ozone was computed in both models to be largest at the highest SH latitudes, where reductions of a maximum of about $1 \%$ (GSFC 2-D model) to about $1.5 \%$ (GMI 3-D CTM) are computed several months after the March 2012 SPE period. The maximum total ozone changes are not predicted to occur during the SPE periods when the $\mathrm{HO}_{\mathrm{x}}$ catalytic cycles dominate; rather, the transport of the enhanced $\mathrm{NO}_{\mathrm{y}}$ to lower altitudes (and high ambient ozone amounts) causes more total ozone impact. Total ozone reductions in the $\mathrm{NH}$ are predicted to be $>0.5 \%$ less than those in the SH. Thus, the impact of these SPE periods on total ozone is fairly small and it is unlikely that the perturbation could be detected in total ozone satellite or ground measurements.

Measurements show a 1-2\% total ozone increase from solar min to solar max due to solar ultraviolet radiation changes (e.g., Chandra and McPeters, 1994; Soukharev and Hood, 2006; Swartz et al., 2012) with fairly similar changes at low and high latitudes. The model computed high Southern polar latitude $\left(70-90^{\circ} \mathrm{S}\right)$ impact from the 2012 SPEs on total ozone was found to be a decrease of $>0.5 \%$ for about seven months. The SPE-caused ozone depletion could thus be competitive with solar radiation-induced variations over periods of several months at polar latitudes. Also, the SPE impact is of opposite sign to the solar radiation effect: more SPEs occur near solar max and lead to ozone decreases whereas solar radiation variation near solar max lead to ozone increases. SPE activity during a solar cycle therefore should be considered carefully when examining the solar cycle induced variations on polar ozone.

\section{Conclusions}

The January and March 2012 SPE periods caused substantial perturbations to the Earth's middle atmosphere. In particular, measurements and global model predictions showed impacts on mesospheric $\mathrm{HO}_{\mathrm{x}}, \mathrm{NO}_{\mathrm{x}}$, and ozone. MLS observations of $\mathrm{HO}_{2}$ displayed enhancements up to 1 ppbv due to the January 2012 SPE period and up to $0.8 \mathrm{ppbv}$ due to the March 2012 SPE period in the northern polar mesosphere. The southern polar mesosphere was impacted as well during these SPE periods, however, the increased solar radiation (and enhanced $\mathrm{HO}_{\mathrm{x}}$ loss) impeded the $\mathrm{HO}_{2}$ increase in January. The SPEcaused $\mathrm{HO}_{2}$ enhancements were fairly well simulated with the GSFC 2-D model. Both MLS measurements and GSFC 2-D model predictions indicated middle mesospheric ozone decreases of $>20 \%$ for several days in the northern polar region with maximum depletions $>60 \%$ as a result of both the January and March 2012 SPE periods. Less SPE-caused ozone depletion was observed and simulated in the southern polar region in January 2012 due to the SPEs. Most of this mesospheric ozone depletion was the result of $\mathrm{HO}_{\mathrm{x}}$ catalytic loss cycles.

Both ACE and MIPAS measurements showed large SPEcaused $\mathrm{NO}_{\mathrm{x}}$ enhancements (>20 ppbv) in the northern polar mesosphere for about three weeks past the January 2012 SPE period. The southern polar mesosphere MIPAS observations 
indicated a smaller SPE-caused $\mathrm{NO}_{\mathrm{x}}$ increase $(<20 \mathrm{ppbv})$ as a result of this January 2012 SPE period. The March 2012 SPE period caused $\mathrm{NO}_{\mathrm{x}}$ measured enhancements $>20 \mathrm{ppbv}$ and $>10 \mathrm{ppbv}$ for only several days in the northern and southern polar mesosphere, respectively. The GSFC 2-D model and the GMI 3-D CTM predicted $\mathrm{NO}_{\mathrm{x}}$ increases were slightly smaller (larger) than measured in the northern (southern) polar mesosphere as a result of the January 2012 SPE period. The GSFC 2-D model and GMI 3-D CTM predicted $\mathrm{NO}_{\mathrm{x}}$ enhancements as a result of the March 2012 SPE period were larger than observed in both polar hemispheres.

The GSFC 2-D model and GMI 3-D CTM were used to predict medium-term impacts ( $\sim$ months) from the January and March 2012 SPE periods. Stratospheric ozone was impacted in the polar regions by these solar events due to the transport of SPE-produced $\mathrm{NO}_{\mathrm{y}}$ to lower altitudes. The GMI 3-D CTM predicted significantly larger upper stratospheric ozone destruction in the NH compared to the GSFC 2-D model, with a maximum of $13 \%$. In the SH, the model predictions were generally similar, with a maximum ozone destruction of $8-11 \%$. Total ozone reductions were predicted to be a maximum of $1-1.5 \%$ in the SH polar region due to the SPEs and would not likely be observed in total ozone satellite or ground measurements.

Acknowledgements. We thank the two reviewers for their valuable comments and suggestions that have led to an improved manuscript. C. H. Jackman and E. L. Fleming thank the NASA Headquarters Living With a Star Targeted Research and Technology Program (LWS TR\&T) for support during the time that this manuscript was written. C. H. Jackman and E. L. Fleming were also supported by the NASA Headquarters Atmospheric Composition Modeling and Analysis Program. C. E. Randall and V. L. Harvey were supported by LWS TR\&T grants NNX10AQ54G and NNX08AU44G as well as the NSF Frontiers in Earth System Dynamics "Sun to Ice" grant: NSF AGS 1135432. The Instituto de-Astrofisica de Andalucia team (MLP and BF) was supported by the Spanish MINECO under grant AYA2011-23552 and EC FEDER funds. We thank S. Strahan of the Global Modeling Initiative project for providing access to the GMI 3-D CTM, which was used in this work. We thank S. Steenrod for running the GMI 3-D CTM simulations. We thank J. Bordeaux for some editorial assistance. We thank the NOAA GOES team for providing the solar proton flux data over the Internet. The Atmospheric Chemistry Experiment (ACE), also known as SCISAT, is a Canadian-led mission mainly supported by the Canadian Space Agency and the Natural Sciences and Engineering Research Council of Canada.

Edited by: F.-J. Lübken

\section{References}

Bernath, P. F., McElroy, C. T., Abrams, M. C., Boone, C. D., Butler, M., Camy-Peyret, C., Carleer, M., Clerbaux, C., Coheur, P.-F., Colin, R., DeCola, P., DeMazière, M., Drummond, J. R., Dufour, D., Evans, W. F. J., Fast, H., Fussen, D., Gilbert, K., Jennings,
D. E., Llewellyn, E. J., Lowe, R. P., Mahieu, E., McConnell, J. C., McHugh, M., McLeod, S. D., Michaud, R., Midwinter, C., Nassar, R., Nichitiu, F., Nowlan, C., Rinsland, C. P., Rochon, Y. J., Rowlands, N., Semeniuk, K., Simon, P., Skelton, R., Sloan, J. J., Soucy, M.-A., Strong, K., Tremblay, P., Turnbull, D., Walker, K. A., Walkty, I., Wardle, D. A., Wehrle, V., Zander, R., and Zou, J.: Atmospheric Chemistry Experiment (ACE) mission overview, Geophys. Res. Lett., 32, L15S01, doi:10.1029/2005GL022386, 2005.

Chandra, S. and McPeters, R. D.: The solar cycle variation of ozone in the stratosphere inferred from Nimbus 7 and NOAA 11 satellites, J. Geophys. Res., 99, 20665-20671, 1994.

Considine, D. B., Douglass, A. R., and Jackman, C. H.: Effects of a polar stratospheric cloud parameterization on ozone depletion due to stratospheric aircraft in a two-dimensional model, J. Geophys. Res., 99, 18879-18894, 1994.

Considine, D. B., Douglass, A. R., Connell, P. S., Kinnison, D. E., and Rotman, D. A.: A polar stratospheric cloud parameterization for the global modeling initiative three-dimensional model and its response to stratospheric aircraft, J. Geophys. Res., 105, 3955-3973, 2000.

Damiani, A., Funke, B., Marsh, D. R., López-Puertas, M., Santee, M. L., Froidevaux, L., Wang, S., Jackman, C. H., von Clarmann, T., Gardini, A., Cordero, R. R., and Storini, M.: Impact of January 2005 solar proton events on chlorine species, Atmos. Chem. Phys., 12, 4159-4179, doi:10.5194/acp-12-4159-2012, 2012.

Douglass, A. R. and Kawa, S. R.: Contrast between 1992 and 1997 high-latitude spring Halogen Occultation Experiment observations of lower stratospheric HCl, J. Geophys. Res., 104, 1873918754, 1999.

Douglass, A. R., Jackman, C. H., and Stolarski, R. S.: Comparison of model results transporting the odd nitrogen family with results transporting separate odd nitrogen species, J. Geophys. Res., 94, 9862-9872, 1989.

Duncan, B. N., Strahan, S. E., Yoshida, Y., Steenrod, S. D., and Livesey, N.: Model study of cross-tropopause transport of biomass burning pollution, Atmos. Chem. Phys., 7, 3713-3736, doi:10.5194/acp-7-3713-2007, 2007.

Fischer, H., Birk, M., Blom, C., Carli, B., Carlotti, M., von Clarmann, T., Delbouille, L., Dudhia, A., Ehhalt, D., Endemann, M., Flaud, J. M., Gessner, R., Kleinert, A., Koopman, R., Langen, J., López-Puertas, M., Mosner, P., Nett, H., Oelhaf, H., Perron, G., Remedios, J., Ridolfi, M., Stiller, G., and Zander, R.: MIPAS: an instrument for atmospheric and climate research, Atmos. Chem. Phys., 8, 2151-2188, doi:10.5194/acp-8-2151-2008, 2008.

Fleming, E. L., Jackman, C. H., Considine, D. B., and Stolarski, R. S.: Simulation of stratospheric tracers using an improved empirically based two-dimensional model transport formulation, J. Geophys. Res., 104, 23911-23934, 1999.

Fleming, E. L., Jackman, C. H., Weisenstein, D. K., and Ko, M. K. W.: The impact of inter-annual variability on multidecadal total ozone simulations, J. Geophys. Res., 112, D10310, doi:10.1029/2006JD007953, 2007.

Fleming, E. L., Jackman, C. H., Stolarski, R. S., and Douglass, A. R.: A model study of the impact of source gas changes on the stratosphere for 1850-2100, Atmos. Chem. Phys., 11, 85158541, doi:10.5194/acp-11-8515-2011, 2011.

Funke, B., Baumgaertner, A., Calisto, M., Egorova, T., Jackman, C. H., Kieser, J., Krivolutsky, A., López-Puertas, M., Marsh, D. R., 
Reddmann, T., Rozanov, E., Salmi, S.-M., Sinnhuber, M., Stiller, G. P., Verronen, P. T., Versick, S., von Clarmann, T., Vyushkova, T. Y., Wieters, N., and Wissing, J. M.: Composition changes after the "Halloween" solar proton event: the High Energy Particle Precipitation in the Atmosphere (HEPPA) model versus MIPAS data intercomparison study, Atmos. Chem. Phys., 11, 90899139, doi:10.5194/acp-11-9089-2011, 2011.

Heath, D. F., Krueger, A. J., and Crutzen, P. J.: Solar proton event: Influence on stratospheric ozone, Science, 197, 886-889, 1977.

Jackman, C. H., Frederick, J. E., and Stolarski, R. S.: Production of odd nitrogen in the stratosphere and mesosphere: An intercomparison of source strengths, J. Geophys. Res., 85, 7495-7505, 1980.

Jackman, C. H., Douglass, A. R., Rood, R. B., McPeters, R. D., and Meade, P. E.: Effect of Solar Proton Events on the Middle Atmosphere During the Past Two Solar Cycles as Computed Using a Two-dimensional Model, J. Geophys. Res., 95, 7417-7428, 1990.

Jackman, C. H., Fleming, E. L., Chandra, S., Considine, D. B., and Rosenfield, J. E.: Past, present, and future modeled ozone trends with comparisons to observed trends, J. Geophys. Res., 101, 28753-28767, 1996.

Jackman, C. H., McPeters, R. D., Labow, G. J., Fleming, E. L., Praderas, C. J., and Russell, J. M.: Northern hemisphere atmospheric effects due to the July 2000 solar proton event, Geophys. Res. Lett., 28, 2883-2886, 2001.

Jackman, C. H., DeLand, M. T., Labow, G. J., Fleming, E. L., Weisenstein, D. K., Ko, M. K. W., Sinnhuber, M., and Russell, J. M.: Neutral atmospheric influences of the solar proton events in October-November 2003, J. Geophys. Res., 100, A09S27, doi:10.1029/2004JA010888, 2005.

Jackman, C. H., Roble, R. G., and Fleming, E. L.: Mesospheric dynamical changes induced by the solar proton events in October-November 2003, Geophys. Res. Lett., 34, L04812, doi:10.1029/2006GL028328, 2007.

Jackman, C. H., Marsh, D. R., Vitt, F. M., Garcia, R. R., Fleming, E. L., Labow, G. J., Randall, C. E., López-Puertas, M., Funke, B., von Clarmann, T., and Stiller, G. P.: Short- and medium-term atmospheric constituent effects of very large solar proton events, Atmos. Chem. Phys., 8, 765-785, doi:10.5194/acp-8-765-2008, 2008.

Jackman, C. H., Marsh, D. R., Vitt, F. M., Garcia, R. R., Randall, C. E., Fleming, E. L., and Frith, S. M.: Long-term middle atmospheric influence of very large solar proton events, J. Geophys. Res., 114, D11304, doi:10.1029/2008JD011415, 2009.

Jackman, C. H., Marsh, D. R., Vitt, F. M., Roble, R. G., Randall, C. E., Bernath, P. F., Funke, B., López-Puertas, M., Versick, S., Stiller, G. P., Tylka, A. J., and Fleming, E. L.: Northern Hemisphere atmospheric influence of the solar proton events and ground level enhancement in January 2005, Atmos. Chem. Phys., 11, 6153-6166, doi:10.5194/acp-11-6153-2011, 2011.

Johnston, H. S. and Podolske, J.: Interpretations of stratospheric photochemistry, Rev. Geophys. Space Phys., 16, 491-519, 1978.

Krivolutsky, A. A., Klyuchnikova, A. V., Zakharov, G. R., Vyushkova, T. Y., and Kuminov, A. A.: Dynamical response of the middle atmosphere to solar proton event of July 2000: Threedimensional model simulations, Adv. Space Res., 37, 1602$1613,2006$.
López-Puertas, M., Funke, B., Gil-López, S., von Clarmann, T., Stiller, G. P., Höpfner, M., Kellmann, S., Fischer, H., and Jackman, C. H.: Observation of $\mathrm{NO}_{\mathrm{x}}$ enhancement and ozone depletion in the Northern and Southern Hemispheres after the October-November 2003 solar proton events, J. Geophys. Res., 110, A09S43, doi:10.1029/2005JA011050, 2005a.

López-Puertas, M., Funke, B., Gil-López, S., von Clarmann, T., Stiller, G. P., Höpfner, M., Kellmann, S., Mengistu Tsidu, G., Fischer, H., and Jackman, C. $\mathrm{H} .: \mathrm{HNO}_{3}, \mathrm{~N}_{2} \mathrm{O}_{5}$, and $\mathrm{ClONO}_{2}$ enhancements after the October-November 2003 solar proton events, J. Geophys. Res., 110, A09S44, doi:10.1029/2005JA011051, 2005b.

McPeters, R. D. and Jackman, C. H.: The response of ozone to solar proton events during solar cycle 21: the observations, J. Geophys. Res., 90, 7945-7954, 1985.

Päivärinta, S.-M., Seppälä, A., Andersson, M. E., Verronen, P. T., Thölix, L., and Kyrölä, E.: Observed effects of solar proton events and sudden stratospheric warmings on odd nitrogen and ozone in the polar middle atmosphere, J. Geophys. Res., 118, 6837-6848, doi:10.1002/jgrd.50486, 2013.

Pickett, H. M., Read, W. G., Lee, K. K., and Yung, Y. L.: Observation of night $\mathrm{OH}$ in the mesosphere, Geophys. Res. Lett. 33, L19808, doi:10.1002/2006GL026910, 2006.

Porter, H. S., Jackman, C. H., and Green, A. E. S.: Efficiencies for production of atomic nitrogen and oxygen by relativistic proton impact in air, J. Chem. Phys., 65, 154-167, 1976.

Randall, C. E., Siskind, D. E., and Bevilacqua, R. M.: Stratospheric $\mathrm{NO}_{\mathrm{x}}$ enhancements in the southern hemisphere vortex in winter/spring of 2000, Geophys. Res. Lett., 28, 2385-2388, 2001.

Rinsland, C. P., Boone, C., Nassar, R., Walker, K., Bernath, P., McConnell, J. C., and Chiou, L.: Atmospheric Chemistry Experiment (ACE) Arctic stratospheric measurements of $\mathrm{NO}_{\mathrm{x}}$ during February and March 2004: Impact of intense solar flares, Geophys. Res. Lett., 32, L16S05, doi:10.1029/2005GL022425, 2005.

Sander, S. P., Friedl, R. R., Barker, J. R., Golden, D. M., Kurylo, M. J., Wine, P. H., Abbatt, J. P. D., Burkholder, J. B., Kolb, C. E., Moortgat, G. K., Huie, R. K., and Orkin, V. L.: Chemical kinetics and photochemical data for use in atmospheric studies, Evaluation Number 17, JPL Publication 10-6, 2010.

Sinnhuber, M., Nieder, H., and Wieters, N.: Energetic particle precipitation and the chemistry of the mesosphere/lower thermosphere, Surv. Geophys., 33, 1281-1334, doi:10.1007/s10712012-9201-3, 2012.

Solomon, S., Rusch, D. W., Gerard, J.-C., Reid, G. C., and Crutzen, P. J.: The effect of particle precipitation events on the neutral and ion chemistry of the middle atmosphere, 2, Odd hydrogen, Planet. Space Sci., 29, 885-892, 1981.

Solomon, S., Reid, G. C., Rusch, D. W., and Thomas, R. J.: Mesospheric ozone depletion during the solar proton event of July 13, 1982, 2, Comparison between theory and measurements, Geophys. Res. Lett., 10, 257-260, 1983.

Soukharev, B. E. and Hood, L. L.: Solar cycle variation of stratospheric ozone: Multiple regression analysis of long-term satellite data sets and comparisons with models, J. Geophys. Res., 111, D20314, doi:10.1029/2006JD007107, 2006.

Strahan, S. E., Duncan, B. N., and Hoor, P.: Observationally derived transport diagnostics for the lowermost stratosphere and their application to the GMI chemistry and transport model, 
Atmos. Chem. Phys., 7, 2435-2445, doi:10.5194/acp-7-24352007, 2007.

Strahan, S. E., Douglass, A. R., and Newman, P. A.: The contributions of chemistry and transport to low arctic ozone in March 2011 derived from Aura MLS observations, J. Geophys. Res., 118, 1563-1576, doi:10.1002/jgrd.50181, 2013.

Swartz, W. H., Stolarski, R. S., Oman, L. D., Fleming, E. L., and Jackman, C. H.: Middle atmosphere response to different descriptions of the 11-yr solar cycle in spectral irradiance in a chemistry-climate model, Atmos. Chem. Phys., 12, 5937-5948, doi:10.5194/acp-12-5937-2012, 2012.

Swider, W. and Keneshea, T. J.: Decrease of ozone and atomic oxygen in the lower mesosphere during a PCA event, Planet. Space Sci., 21, 1969-1973, 1973.

Verronen, P. T., Seppälä, A., Kyrola, E., Tamminen, J., Pickett, H. M., and Turunen, E.: Production of odd hydrogen in the mesosphere during the January 2005 solar proton event, Geophys. Res. Lett., 33, L24811, doi:10.1029/2006GL028115, 2006.

Verronen, P. T., Funke, B., López-Puertas, M., Stiller, G. P., von Clarmann, T., Glatthor, N., Enell, C.-F., Turunen, E., and Tamminen, J.: About the increase of $\mathrm{HNO}_{3}$ in the stratopause region during the Halloween 2003 solar proton event, Geophys. Res. Lett., 35, L20809, doi:10.1029/2008GL035312, 2008.

Verronen, P. T., Rodger, C. J., Clilverd, M. A., and Wang, S.: First evidence of mesospheric hydroxyl response to electron precipitation from the radiation belts, J. Geophys. Res., 116, D07307, doi:10.1029/2010JD014965, 2011a.
Verronen, P. T., Santee, M. L., Manney, G. L., Lehmann, R., Salmi, S.-M., and Seppälä, A.: Nitric acid enhancements in the mesosphere during the January 2005 and December 2006 solar proton events, J. Geophys. Res., 116, D17301, doi:10.1029/2011JD016075, $2011 \mathrm{~b}$.

von Clarmann, T., Glatthor, N., Höpfner, M., Kellmann, S., Ruhnke, R., Stiller, G. P., Fischer, H., Funke, B., Gil-López, S., and López-Puertas, M.: Experimental evidence of perturbed odd hydrogen and chlorine chemistry after the October 2003 solar proton events, J. Geophys. Res., 110, A09S45, doi:10.1029/2005JA011053, 2005.

von Clarmann, T., Funke, B., López-Puertas, M., Kellmann, S., Linden, A., Stiller, G. P., Jackman, C. H., and Harvey, V. L.: The solar proton events in 2012 as observed by MIPAS, Geophys. Res. Lett., 40, 464-469, doi:10.1002/grl.50119, 2013.

WMO (World Meteorological Organization), Scientific Assessment of Ozone Depletion: 2010, Global Ozone Research and Monitoring Project-Report No. 52, Geneva, Switzerland, 2011.

Yando, K., Millan, R. M., Green, J. C., and Evans, D. S.: A Monte Carlo simulation of the NOAA POES Medium Energy Proton and Electron Detector instrument, J. Geophys. Res., 116, A10231, doi:10.1029/2011JA016671, 2011. 